\title{
ORGANIC MATTER CHANGES IMMEDIATELY AFTER A WILDFIRE IN AN ATLANTIC FOREST SOIL AND COMPARISON WITH LABORATORY SOIL HEATING
}

\author{
I. FERNÁNDEZ, A. CABANEIRO and T. CARBALLAS* \\ Instituto de Investigaciones Agrobiológicas de Galicia, C.S.I.C. Apartado 122, 15780 Santiago de \\ Compostela, Spain
}

(Accepted 6 September 1996)

\begin{abstract}
Summary-The quantity, chemical composition and mineralization kinetics of the organic matter of an acid Humic Cambisol, developed over granite, under Pinus sylvestris L. were determined in 0-5 and 5$10 \mathrm{~cm}$ samples collected immediately after a high-intensity wildfire, and compared with those of an unaffected site nearby. Organic matter was characterized by different chemical fractionation methods, and the $C$ mineralization was determined by aerobic incubation. $A$ similar unburnt soil located in the same area vas heated at the laboratory at $150,220,350$ and $490^{\circ} \mathrm{C}$ to measure the losses of $\mathrm{C}$ content; the samples heated at 220 and $350^{\circ} \mathrm{C}$ were selected to determine chemical changes in organic matter composition. Surface and subsurface soil layers lost about $50 \%$ of their $\mathrm{C}$ content during wildfire. The $\mathrm{C}$ mineralized decreased in the surface layer; however, the percentage of total $\mathbf{C}$ mineralized increased in both layers. The cumulative $\mathrm{CO}_{2}-\mathrm{C}$ mineralized fitted a double exponential first-order kinetic model, but the fire affected the kinetic parameters, increasing both the labile pool of the potentially mineralizable $\mathrm{C}$ and the mineralization rate constants of the recalcitrant and labile pools. Cellulose + hemicelluloses declined significantly after the burning, whereas lipids did not vary. The fire decreased the amount of unhumified organic matler and the alkali-soluble compounds, particularly humic acids, but there was a net increase of humin. The organic matter bound to $\mathrm{Fe}$ and especially to $\mathrm{Al}$ was much higher after the burning. In the soil heated under laboratory conditions the changes observed at $150^{\circ} \mathrm{C}$ were very low, whereas at $490^{\circ} \mathrm{C}$ almost all the organic matter disappeared. The changes exhibited by the samples heated at $220^{\circ} \mathrm{C}$ were the most similar to those observed in the samples from the wildfire. At 220 and $350^{\circ} \mathrm{C}$ the humification and metal complexation percentages of the organic matter increased, similar to the trend observed in the samples from the wildfire. (C) 1997 Elsevier Science Ltd
\end{abstract}

\section{INTRODUCTION}

The changes induced by fires on vegetation and soil characteristics have been studied for a long time. Vegetation fires are considered to be a natural phenomenon in many parts of the world, where repeated fires have resulted in maintaining particular ecosystems (Ahlgren and Ahlgren, 1960). In such areas controlled fires are widely used to reduce accumulated fuel and thus limit the risk of highintensity wildfires. Reports are available on controlled fires (Chandler et al., 1983; Khanna and Raison, 1986; Marion et al., 1991) and soil heating under laboratory conditions (Kang and Sajjapongse, 1980), and their influence on soil properties such as $\mathbf{p H}$, loss and availability of nutrients (Feller, 1988). Studies on high-intensity wildfires are scarce and, moreciver, most were undertaken after some time had lapsed since the fire.

The northwest of Spain, which is located in the temperate-humid climate zone, contains soils which are rich in organic matter, and are acidic and

*Author for correspondence. sandy. This region had been considered in the past to be a relatively low-risk wildfire area, because of its climate and the nature of floristic composition of its forests. Deciduous species such as oak, chestnut, birch and alder in the natural forests of this area possess an intrinsic high resistance to fires. During the last two centuries the landscape of this region was greatly modified by human activities which included growing evergreen trees, particularly resinous, types which are more vulnerable to fire. Consequently, in recent decades the number of wildfires has dramatically increased. These fires adversely affect vegetation cover and soils. In some cases soil erosion produced irreversible damage, with consequent economic losses and landscape deterioration. Díaz-Fierros et al. $(1982,1987)$ found that the erosion risk increased considerably during the first year after a fire. These authors reported an average soil erosion of $56 \mathrm{t} \mathrm{ha}^{-1}$ for this period, the risk declining exponentially to negligible amounts after 12 months.

In sandy soils the main factor of cohesion and protection against erosion when the fires destroy the vegetation cover is a high content of organic 
matter which, in this area, is maintained even after high-intensity wildfires (Bará, 1981). The organic matter also produces the adequate conditions for the establishment of new vegetation contributing to soil regeneration. Studies on the effects of fires on organic matter content are quite common (e.g. Kang and Sajjapongse, 1980; Giovannini et al., 1987; Kutiel and Kutiel, 1989); however, those on changes in organic matter composition (Shindo and Urabe, 1993), structure (Almendros et al., 1992) and biological characteristics (Vázquez et al., 1993; Fritze et al., 1994; Acea and Carballas, 1996) are less so. There are studies on organic matter composition and mineralization in the soils of the northwest of Spain (Carballas et al., 1979, 1980, 1983; Beloso et al., 1993), but until now the effect of fires on these characteristics had not been studied.

Organic matter is responsible for forest ecosystems productivity because of its nutrient content and its influence on physico-chemical and biological characteristics. Because of this the aim of the study was to evaluate the effects of fire on the composition, stability and $\mathrm{C}$ mineralization of the soil organic matter immediately after a high-intensity wildfire.

\section{MATERIALS AND METHODS}

The soils selected for study were two Humic Cambisols under a pine forest of Pinus sylvestris, developed over granite and located in Cabeza de Manzaneda (Orense, northwest Spain) at $1740 \mathrm{~m}$ above sea level. The undergrowth consisted of Chamaespartium tridentatum (L.) P. Gibbs, Vaccinium myrtilus L., Erica spp and species of Gramineae. The burnt soil was sampled in September, $1 \mathrm{~d}$ after a high-intensity wildfire; simultaneously an unburnt soil from the same edaphic and pine stand located close to the burnt area was sampled and used as a control. Soil samples were collected at $0-5$ and $5-10 \mathrm{~cm}$ depth all along a continuous profile $10 \mathrm{~m}$ in length. They were sieved ( $4 \mathrm{~mm}$ ), and the fraction less than $4 \mathrm{~mm}$ was homogenized. Fresh samples were used for the study of $\mathrm{C}$ mineralization. Air-dried samples were employed for the determination of organic matter and the other soil characteristics.

For the experiments on soil heating under laboratory conditions a different unburnt soil from the same area, but far from the burnt zone, was used. The sample was collected in October, in the same way as the others from $0-5 \mathrm{~cm}$, using a subsample as control. The soil was heated in an oven with a timer and a heating rate programme. Temperature in the soil was controlled by a thermocouple located into the bulk of soil. Conditions of heating were as follows: an increase of $3^{\circ} \mathrm{C} \mathrm{min}$ to prevent the sudden combustion produced when reaching the soil ignition temperature; $30 \mathrm{~min}$ of heating after reaching the selected heating temperature; and a sample size of less than $1 \mathrm{~cm}$ depth to avoid a temperature gradient in the profile. The soil was treated at the ignition temperature $\left(220^{\circ} \mathrm{C}\right.$; Salgado et al., $1995)$ and at temperatures lower $\left(150^{\circ} \mathrm{C}\right)$ and higher (350 and $490^{\circ} \mathrm{C}$ ) than the ignition temperature. Losses of organic matter were determined in all the samples. According to these losses the samples heated at 220 and $350^{\circ} \mathrm{C}$ were selected for subsequent organic matter fractionation. The same fractionation procedure was followed in the control sample.

The methods described by Guitián Ojea and Carballas (1976) were used to determine the following soil properties: field capacity (at $10 \mathrm{KPa}$ in a Richard's membrane-plate extractor); $\mathrm{pH}$ in $\mathrm{H}_{2} \mathrm{O}$ (1:2.5); $\mathrm{pH}$ in $1 \mathrm{~N} \mathrm{KCl} \mathrm{(1:2.5);} \mathrm{extractable} \mathrm{Fe}$ and $\mathrm{Al}$ oxides (by extraction with a mixture of hydrosulphite and Tamm's reagent). $\mathrm{C}$ content was determined by combustion and measurement of the $\mathrm{CO}_{2}$ in a Carmhograph 12 with the primary oven at $900^{\circ} \mathrm{C}$ and the secondary oven at $400^{\circ} \mathrm{C}$. The factor used to convert $\mathrm{C}$ into organic matter was 1.724 (Guitián Ojea and Carballas, 1976). Total N content was determined by Kjeldahl digestion using the method developed by Bremner (1965). The results are the average of three replicate determinations.

Analysis of C-containing compounds was performed by the method of Kononova (1961), except for water-soluble compounds that were extracted as recommended by Stevenson (1965). The water-soluble fraction was extracted by refluxing with boiling water for $2 \mathrm{~h}$. Lipids were extracted from the residue with ethanol-benzene for $24 \mathrm{~h}$ in a Soxhlet. The residue was treated with $\mathrm{H}_{2} \mathrm{SO}_{4}$ to solubilize cellulose and hemicelluloses leaving lignin and mineral material as a residue. After ignition of this residue in an oven at $500^{\circ} \mathrm{C}$ for $6 \mathrm{~h}$ the lignin content was calculated by difference from the final residue weight (González-Prieto et al., 1993). The results were expressed as percentage of either soil weight or total organic matter.

To study the humified organic matter of the 0$5 \mathrm{~cm}$ soil layer a modified method of Duchaufour and Jacquin (1966) was used. After a densiometric separation of the unhumified and the humified organic matter using bromoform-ethanol with a density of 1.8 , the humified organic compounds were extracted successively by $1 \% \mathrm{Na}_{4} \mathrm{P}_{2} \mathrm{O}_{7}$ (pH 9.8) and $0.1 \mathrm{~N} \mathrm{NaOH}(\mathrm{pH} \mathrm{13})$. The extraction was performed by agitating soil with the corresponding reagent for $1 \mathrm{~h}$, centrifugation and repetition of the cycle an additional time. The final residue, which was composed of the humin fraction $(\mathrm{H})$, was dried at $40^{\circ} \mathrm{C}$, ground and homogenized. In each extract humic acids (HA) were separated from fulvic acids (FA) by precipitation at $\mathrm{pH} 1$ with $\mathrm{H}_{2} \mathrm{SO}_{4}$ and centrifugation after more than $4 \mathrm{~h}$ of standing (GonzálezPrieto et al., 1993). C was determined in each 
extract by Sauerlandt's method (Guitián Ojea and Carballas, 1976) which used $\mathrm{Cr}_{2} \mathrm{O}_{7} \mathrm{~K}_{2}+\mathrm{H}_{2} \mathrm{SO}_{4}$ for digestion and further titration with $\left(\mathrm{NH}_{4}\right)_{2} \mathrm{SO}_{4} \cdot \mathrm{FeSO}_{4} \cdot 6 \mathrm{H}_{2} \mathrm{O}$. The residue $\mathrm{C}$ content was assessed using the Carmhograph method. Fe and $\mathrm{Al}$ bound to the organic matter was assessed by determining these elements in the alkali-extracts by atomic spectrophotometry. The per cent extraction $\left(C_{\mathrm{FA}}+\right.$ HA total $\left.\mathrm{C}^{-1}\right)$, per cent humification $\left(C_{\mathrm{FA}}+\mathrm{HA}+\mathrm{H}\right.$ total $\left.\mathrm{C}^{-1}\right)$ and indices of polymerization, fulvic acids to humic acids ratio (FA-to-HA), and metal complexation, $(\mathrm{Fe}+\mathrm{Al})$-to- $\mathrm{C}$ ratio, were calculated.

Fresh samples or samples stored at $4^{\circ} \mathrm{C}$ for less than $7 \mathrm{~d}$ were used for the determination of the $\mathrm{C}$ mineralization kinetics by aerobic incubation of the unburnt and the burnt soil samples from the wildfire. The incubation method was that of Guckert $e t$ al. (1968) modified by Choné et al. (1974), who used an intermittent air flow for aeration. Five replicates of $50 \mathrm{~g}$ soil from each sample were placed into $500 \mathrm{ml}$ Erlenmeyer flasks and maintained at $28^{\circ} \mathrm{C}$ and moisture at $75 \%$ of field capacity for $11 \mathrm{wk}$. The flask atmospheres were periodically renewed with $\mathrm{CO}_{2}$-free air, and the $\mathrm{CO}_{2}$ evolved was trapped by bubbling for $2 \mathrm{~h}$ in $40 \mathrm{ml}$ of $2 \mathrm{~N}$ $\mathrm{NaOH}$. From $5 \mathrm{ml} \mathrm{NaOH}$ solution, the $\mathrm{Na}_{2} \mathrm{CO}_{3}$ formed was precipitated by $20 \% \mathrm{BaCl}_{2}$ solution and then the remaining $\mathrm{NaOH}$ was measured by titration against $0.2 \mathrm{~N} \mathrm{HCl}$ using a Metrohm 682 titrator. The $\mathrm{CO}_{2}$ was then quantified by subtraction, using two empty flasks incubated under the same conditions as the control (Carballas et al., 1979; González-Prieto et al., 1991; Beloso et al., 1993). After $77 \mathrm{~d}$ of incubation, $\mathrm{pH}$ in water and $\mathrm{KCl}$ were determined in the burnt and the unburnt samples. The $\mathrm{C}$ mineralization, expressed as $\mathrm{g} \mathrm{CO}_{2}-$ $\mathrm{C}$ evolved $\mathrm{kg}^{-1}$ soil, and the $\mathrm{C}$ mineralization coefficient expressed as a percentage of the total $\mathrm{C}$ were calculated.

The cumulative curves of $\mathrm{CO}_{2}-\mathrm{C}$ release over time followed the double exponential model proposed by Andrín and Pauskian (1987) and employed by Updegraff et al. (1995) to quantify the kinetics of $\mathrm{C}$ release from different soils under different conditions:

$$
C_{\mathrm{t}}=C_{0}\left(1-\mathrm{e}^{-k t}\right)+\left(T C-C_{0}\right)\left(1-\mathrm{e}^{-h t}\right)
$$

where $C_{\mathrm{t}}$ is the cumulative $\mathrm{C}$ released after time $t$ (days), $C_{0}$ is the potentially mineralizable $\mathrm{C}$ in a labile pool with a instantaneous mineralization rate $k\left(\mathrm{~d}^{-1}\right), T C$ is the total amount of $\mathrm{C}$ present in the soil sample $\left(\mathrm{g} \mathrm{kg}^{-1}\right)$ and $\left(T C-C_{0}\right)$ is the amount of $C$ in a recalcitrant pool with a instantaneous mineralization rate $h\left(\mathrm{~d}^{-1}\right)$. This model explains the overall $\mathrm{C}$ mineralization process by considering two pools of $\mathrm{C}$ that decay independently and in parallel, with different degradation rates. The non-linear parameter estimation procedures in SPSS.5.0.1. for Windows were used to fit the experimental data to the model. To avoid errors in the parameter estimation the convergence criteria indicated by Updegraff et al. (1995) were used.

Two-way ANOVA test was applied to weekly C mineralization data to follow the kinetic variations as well as to quantify the variation of $\mathrm{C}$ mineralization attributable to the burnt soil and to the location of the layer in the profile. The least significant difference (LSD) test (Tukey, 1953) at the 95 and $99 \%$ probability levels was applied to the results. The $\chi^{2}$ test was used for comparison of the results obtained in the different organic matter fractionations.

\section{RESULTS AND DISCUSSION}

Table 1 shows the main characteristics of the soil samples. The unburnt soil varied little in depth, was highly acid, had a high content of organic $\mathrm{C}$ and $\mathrm{N}$, high values of cation exchange capacity (CEC), with a low percentage of base saturation and a moderate content of extractable $\mathrm{Fe}$ and $\mathrm{Al}$ oxides.

Immediately after the fire the increase of $\mathrm{pH}$ was moderate (Table 1) due to the high value of the buffer capacity index (Guitián Ojea and Carballas, 1976) of this soil (5.99) and the short time that had elapsed after the fire. Therefore, it is probably that pH had not yet reached its maximum value. This

Table 1. Main characteristics of the unburnt (UB), the burnt (B), the unheated (UH) and the heated (H) soil samples (mean values \pm SD)

\begin{tabular}{|c|c|c|c|c|c|c|c|c|c|c|}
\hline Sample & Depth (cm) & $\mathrm{pH} \mathrm{H}_{2} \mathrm{O}$ & $\mathrm{pH} \mathrm{KCl}$ & $\mathrm{C}\left(\mathrm{g} \mathrm{kg}^{-1}\right)$ & C-to-N & $\mathrm{N}\left(\mathrm{g} \mathrm{kg}^{-1}\right)$ & $\begin{array}{c}\mathrm{Fe}_{2} \mathrm{O}_{3} \\
\left(\mathrm{~g} \mathrm{~kg}^{-1}\right)\end{array}$ & $\begin{array}{c}\mathrm{Al}_{2} \mathrm{O}_{3} \\
\left(\mathrm{~g} \mathrm{~kg}^{-1}\right)\end{array}$ & $\begin{array}{c}\text { CEC } \\
(m e q) \\
\left.g^{-1}\right)\end{array}$ & $\begin{array}{c}\text { Base } \\
\text { saturation } \\
(\%)\end{array}$ \\
\hline 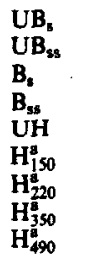 & $\begin{array}{l}0-5 \\
5-10 \\
0-5 \\
5-10 \\
0-5 \\
0-5 \\
0-5 \\
0-5 \\
0-5\end{array}$ & $\begin{array}{l}4.19 \pm 0.02 \\
4.25 \pm 0.03 \\
4.74 \pm 0.03 \\
4.58 \pm 0.03 \\
4.35 \pm 0.03 \\
4.00 \pm 0.02 \\
4.05 \pm 0.02 \\
5.70 \pm 0.05 \\
6.35 \pm 0.04\end{array}$ & $\begin{array}{l}3.29 \pm 0.01 \\
3.45 \pm 0.01 \\
4.00 \pm 0.00 \\
3.78 \pm 0.03 \\
3.30 \pm 0.01 \\
3.30 \pm 0.03 \\
3.15 \pm 0.02 \\
4.75 \pm 0.03 \\
5.45 \pm 0.05\end{array}$ & $\begin{array}{r}158.2 \pm 1.8 \\
111.0 \pm 1.8 \\
74.4 \pm 1.0 \\
51.1 \pm 2.1 \\
102.9 \pm 1.1 \\
105.1 \pm 0.1 \\
64.8 \pm 0.1 \\
10.7 \pm 0.0 \\
0.3 \pm 0.0\end{array}$ & $\begin{array}{c}18 \\
18 \\
15 \\
15 \\
19 \\
19 \\
12 \\
8 \\
\text { ND }\end{array}$ & $\begin{array}{l}8.73 \pm 0.10 \\
6.30 \pm 0.14 \\
4.87 \pm 0.15 \\
3.31 \pm 0.07 \\
5.49 \pm 0.06 \\
5.50 \pm 0.02 \\
5.40 \pm 0.01 \\
1.40 \pm 0.01 \\
0.10 \pm 0.00\end{array}$ & $\begin{array}{l}5.5 \pm 0.1 \\
6.5 \pm 0.1 \\
4.9 \pm 0.3 \\
4.7 \pm 0.0 \\
5.5 \pm 0.1 \\
5.6 \pm 0.1 \\
5.0 \pm 0.2 \\
5.4 \pm 0.1 \\
5.6 \pm 0.1\end{array}$ & $\begin{array}{l}6.3 \pm 0.4 \\
7.8 \pm 0.5 \\
6.1 \pm 0.3 \\
6.1 \pm 0.1 \\
6.3 \pm 0.1 \\
6.8 \pm 0.9 \\
6.2 \pm 0.0 \\
7.1 \pm 0.0 \\
8.6 \pm 0.1\end{array}$ & $\begin{array}{c}51.8 \pm 0.1 \\
49.7 \pm 1.5 \\
24.2 \pm 1.5 \\
33.8 \pm 1.1 \\
43.9 \pm 0.4 \\
\text { ND } \\
\text { ND } \\
\text { ND } \\
\text { ND }\end{array}$ & $\begin{array}{r}5.7 \pm 0.4 \\
3.3 \pm 0.4 \\
13.2 \pm 0.3 \\
3.6 \pm 0.2 \\
3.1 \pm 0.0 \\
\text { ND } \\
\text { ND } \\
\text { ND } \\
\text { ND }\end{array}$ \\
\hline
\end{tabular}

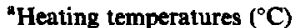

ND $=$ not determined 
Table 2. Carbon mineralization capacity (mean values \pm SD), kinetic parameters for $C$ mineralization model based on equation 1 (estimate values \pm asymptotic SE) and $\mathrm{pH}$ of the surface (s) and subsurface layer (ss) of the unburnt (UB) and the burnt (B) soil samples after 11 weeks of incubation (mean values $\pm \mathrm{SD}$ )

\begin{tabular}{|c|c|c|c|c|c|c|c|c|}
\hline \multirow[b]{2}{*}{ Sample } & \multirow{2}{*}{$\begin{array}{l}\text { Mineralized C } \\
\left(\mathrm{g} \mathrm{kg}^{-1}\right)\end{array}$} & \multirow{2}{*}{ 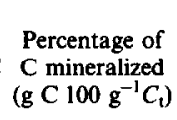 } & \multicolumn{4}{|c|}{ Kinetic parameters } & \multicolumn{2}{|c|}{$\mathrm{pH}$} \\
\hline & & & $C_{0}\left(\mathrm{~g} \mathrm{~kg}^{-1}\right)$ & $k$ & $h \times 10^{4}$ & $R^{2}$ & $\mathrm{H}_{2} \mathrm{O}$ & $\mathrm{KCl}$ \\
\hline $\begin{array}{l}\mathrm{UB}_{\mathrm{s}} \\
\mathrm{UB}_{\mathrm{ss}} \\
\mathbf{B}_{\mathrm{s}} \\
\mathbf{B}_{\mathrm{ss}}\end{array}$ & $\begin{array}{l}3.41 \pm 0.09^{\mathrm{c}} \\
1.97 \pm 0.07^{\mathrm{a}} \\
2.58 \pm 0.07^{\mathrm{b}} \\
1.99 \pm 0.06^{\mathrm{a}}\end{array}$ & $\begin{array}{l}2.15 \pm 0.05^{\mathrm{b}} \\
1.77 \pm 0.06^{\mathrm{a}} \\
3.47 \pm 0.10^{\mathrm{c}} \\
3.89 \pm 0.12^{\mathrm{d}}\end{array}$ & $\begin{array}{l}0.67+0.02 \\
0.34 \pm 0.01 \\
1.06 \pm 0.02 \\
0.48 \pm 0.01\end{array}$ & $\begin{array}{l}0.105+0.005 \\
0.159 \pm 0.011 \\
0.184 \pm 0.008 \\
0.173 \pm 0.008\end{array}$ & $\begin{array}{l}2.29 \pm 0.02 \\
1.94 \pm 0.02 \\
2.80 \pm 0.06 \\
3.98 \pm 0.04\end{array}$ & $\begin{array}{l}0.9998 \\
0.9995 \\
0.9986 \\
0.9996\end{array}$ & $\begin{array}{l}4.00 \pm 0.0 \\
3.95 \pm 0.0 \\
5.12 \pm 0.0 \\
5.00 \pm 0.0\end{array}$ & $\begin{array}{l}3.15 \pm 0.02 \\
3.26 \pm 0.02 \\
4.05 \pm 0.01 \\
3.45 \pm 0.03\end{array}$ \\
\hline
\end{tabular}

${ }^{\mathrm{a}-\mathrm{d}}$ Values within columns with dissimilar letters are significantly different $(P \leq 0.01)$.

$C_{0}$, potentially mineralizable $\mathrm{C}$ of the labile pool.

$k$, instantaneous mineralization rate of the labile $\mathrm{C}$ pool.

$h$, instantaneous mineralization rate of the recalcitrant $\mathrm{C}$ pool.

agrees with the higher $\mathrm{pH}$ in water exhibited by the burnt soil after incubation which was not found in the unburnt soil (Table 2). Chandler et al. (1983) attributed the increase of $\mathrm{pH}$ after burning not only to fire intensity, but also to soil characteristics. Ulery et al. (1993) gave the loss of organic acids during the fire and the addition of hydroxides and carbonates by the ashes as some of the reasons for the increase in $\mathrm{pH}$. The percentage of base saturation increased and the CEC decreased as a consequence of the disappearance of organic matter due to fire (Table 1).

In the soil heated at $150^{\circ} \mathrm{C}$ there were no significant changes in most of the soil characteristics except a low decrease of $\mathrm{pH}$ which was also observed at $220^{\circ} \mathrm{C}$ (Table 1). At $350^{\circ} \mathrm{C}$ the $\mathrm{pH}$ was more than one unit higher and at $490^{\circ} \mathrm{C}$ it was two units higher than that of the control soil. The low decrease of $\mathrm{pH}$ at the lower temperatures as well as the high increase at the higher temperatures agreed with the findings of Nishita and Haug (1972), Giovannini et al. (1990) and Diaz-Raviña et al. (1992). Extractable $\mathrm{Al}$ oxides also decreased at $220^{\circ} \mathrm{C}$, which was similar to that of the wildfire, and showed an increase at 350 and $490^{\circ} \mathrm{C}$. In the case of $\mathrm{Fe}$, a decrease was only observed in the soil sample heated at $220^{\circ} \mathrm{C}$.

\section{Organic matter content}

The $\mathrm{C}$ content had decreased considerably after the fire. The decrease was approximately $50 \%$ in the whole depth studied (Table 1); however, it is likely that $\mathrm{C}$ losses were even higher in the surface layer, which was much more morphologically altered, and that they had been partially compensated by deposition of plant material not completely incinerated. Chandler et al. (1983) reported the great variability of the effect of fire on organic matter content ranging from a total destruction of the organic matter due to wildfires to increases that can reach $30 \%$ in the surface layers as a consequence of organic material redistribution in the profile. The loss of $\mathbf{C}$ was accompanied by a lower $\mathbf{N}$ decrease and consequently the $\mathrm{C}$-to- $\mathrm{N}$ ratio also decreased from 18 (characteristic of a moder forest humus) to 15 after the fire. The soil heated at $150^{\circ} \mathrm{C}$ did not exhibit a significant loss of $\mathrm{C}$, whereas at $490^{\circ} \mathrm{C}$ almost all the organic matter had disappeared (Table 1). In the soil heated at $220^{\circ} \mathrm{C}, 37 \%$ of $\mathrm{C}$ was lost and at $350^{\circ} \mathrm{C}$ the loss was $90 \%$ of the total C. The C-to- $\mathrm{N}$ ratio dramatically decreased in the soil heated at $220^{\circ} \mathrm{C}$, declining to a value of 8 in the soil heated at $350^{\circ} \mathrm{C}$.

\section{C mineralization activity}

Figure 1, which shows the cumulated percentage of $\mathrm{C}$ mineralized, indicates that the wildfire not only affected the percentage of $\mathrm{C}$ mineralized by the end of incubation, but also altered the $\mathrm{C}$ mineralization kinetics during the incubation.

The $\mathrm{C}$ mineralization coefficient was relatively low ( $\approx 2 \%$ of total $\mathrm{C}$ after $11 \mathrm{wk}$ ) in the unburnt soil. At the end of the incubation this coefficient as well as the total amount of $\mathrm{C}$ mineralized were statistically different $(P \leq 0.01)$ in both soil layers (Table 2). Low values for endogenous $C$ mineralization coefficient are usual in soils over granite of similar characteristics from the same area (Carballas et al., 1979; Beloso et al., 1993).

The $\mathrm{CO}_{2}-\mathrm{C}$ evolved from the surface layer of the burnt soil was significantly lower $(P \leq 0.01)$ than that of the same layer from the unburnt soil (Table 2). This result agrees with that found by Almendros et al. (1984a) for soils under a mixed forest, collected $2 \mathrm{y}$ after the fire. The $\mathrm{C}$ mineralization coefficient in the surface layer of the burnt soil was significantly higher $(P \leq 0.05)$ than that of the corresponding layer of the unburnt soil throughout the incubation period (Fig. 1) as a consequence of the high loss of $\mathrm{C}$ after the fire. In the subsurface soil, fire did not significantly affect the amount of organic matter mineralized (Table 2). Nevertheless, like the surface soil, the $\mathrm{C}$ mineralization coefficient increased significantly $(P \leq 0.01)$ and after $11 \mathrm{wk}$ incubation was twice that of the unburnt soil (see Fig. 1 and Table 2).

After burning, the surface soil exhibited a high initial loss of $\mathrm{CO}_{2}-\mathrm{C}$ that declined sharply after 


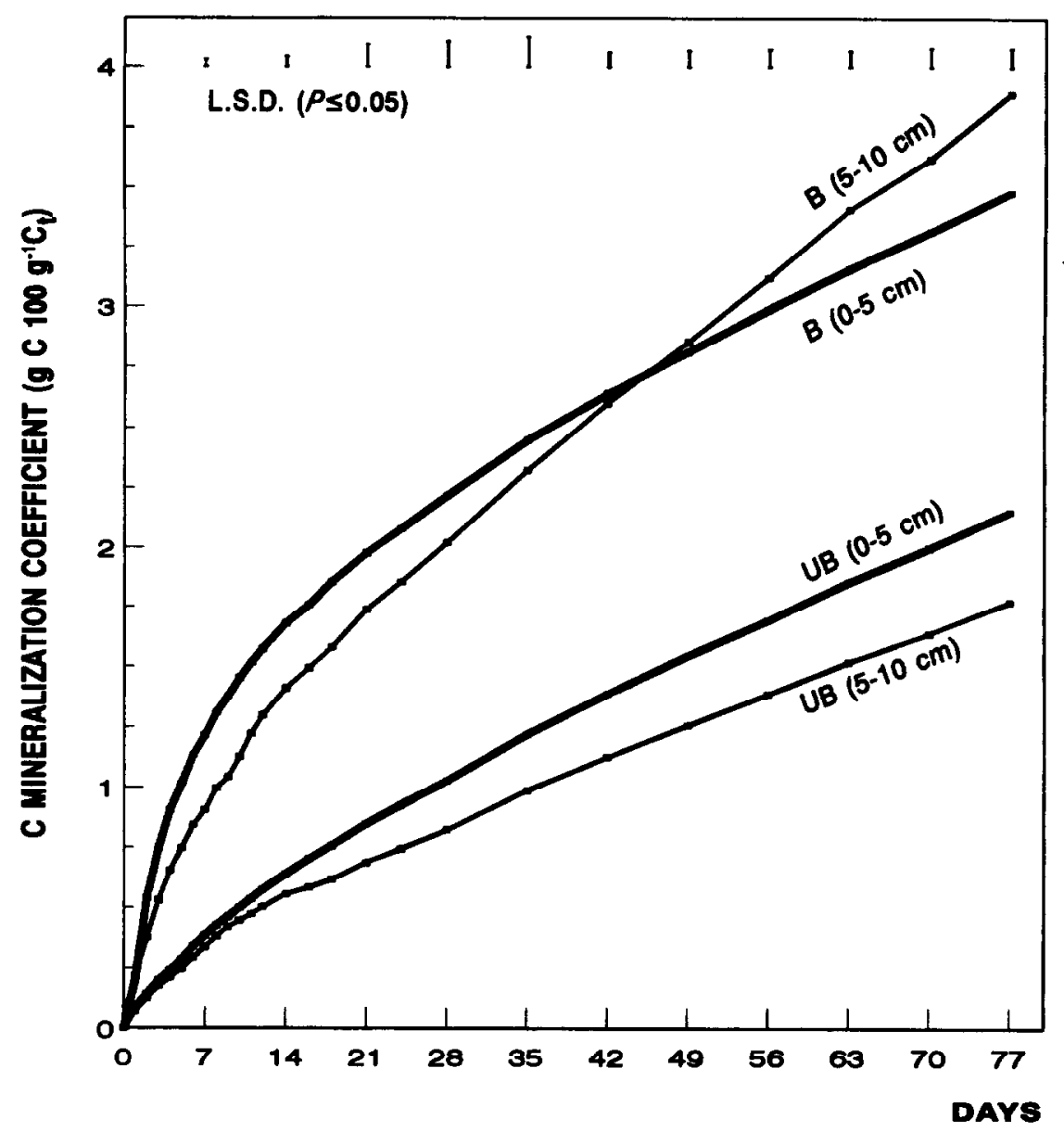

Fig. 1. Curnulative $\mathrm{C}$ mineralization coefficient during incubation of the $0-5$ and $5-10 \mathrm{~cm}$ layers of the unburnt (UB) and the burnt (B) soils just after the wildfire. Least significant difference $(P \leq 0.05)$ shown as bars at week intervals.

$14 \mathrm{~d}$ of incubation; by this period the slope of the curve diminished and was practically parallel to that of the contrcl soil (Fig. 1). The subsurface soil also exhibited an initial high value of $\mathrm{CO}_{2}$ evolved, although lower than that observed in the $0-5 \mathrm{~cm}$ layer. After $42 \mathrm{~d}$ the $\mathrm{CO}_{2}$ evolved by the subsurface soil was higher than that evolved by the surface soil, the difference between both values were signifcant from week $8(P \leq 0.05)$ until the end of the incubation $(P \leq 0.01)$. The two-way ANOVA test indicated a significant interaction between the burnt-unburnt factor and the depth of soil (0$5 \mathrm{~cm} / 5-10 \mathrm{~cm}$ ).

The cumulative curve of $\mathrm{CO}_{2}-\mathrm{C}$ evolved by the different soil samples significantly fitted the firstorder equation proposed by Stanford and Smith (1972), which was successfully used by Zak et al. (1993) to descritie the mineralization kinetics in native soils and by Prieto-Fernández et al. (1993) in native and burned soils. However, as in the case of Díaz-Fierros et al. (1988) for $\mathrm{N}$ mineralization and Updegraff et al. (1995) for $\mathrm{C}$ and $\mathrm{N}$ mineralization kinetics, the $\mathrm{CO}_{2} \cdot \mathrm{C}$ data evolved by the soils stu- died showed a superior fit to a double exponential model; the kinetic parameters obtained using the model proposed by Andrén and Pauskian (1987) are shown in Table 2 . The values of these parameters showed the differences between the kinetics of the burnt and unburnt soils. The fire increased the potentially mineralizable $\mathrm{C}$ of the labile pool, which was 1.6- and 1.4-fold higher in the surface and the subsurface layer, respectively, of the burnt soil than that in the corresponding layers of the unburnt soil. In general the mineralization rate constants were also increased by the burning. For the labile pool the kinetic constant $(k)$ was multiplied by 1.8 in the surface layer of the burned soil, whereas it did not vary in the subsurface layer. In contrast, for the recalcitrant pool the mineralization rate $(h)$ duplicated after the fire in the subsurface layer and increased only 1.2-fold in the surface layer.

\section{C-containing compounds}

The organic matter content in the surface and the subsurface soil layers from unburnt site was 27.3 
\% $0 . m$.

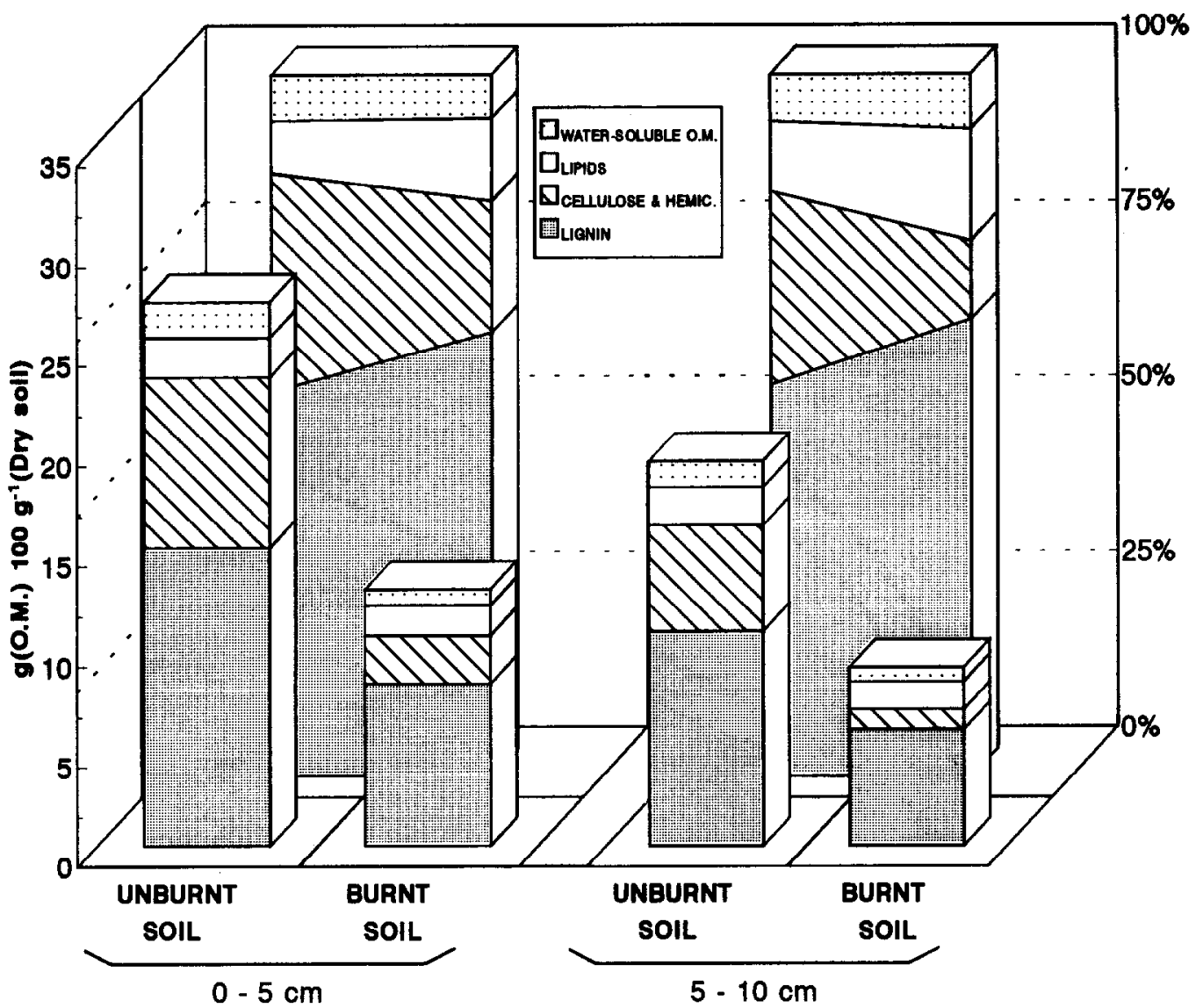

Fig. 2. Content (foreground of the figure) and changes in the percentage distribution (background) of the main groups of C-containing compounds of the organic matter from the $0-5$ and $5-10 \mathrm{~cm}$ layers of the unburnt and the burnt soils.

and $19.1 \%$, respectively, and the composition of the organic matter was similar in both soil layers as shown by the percentage distribution of the different fractions (Fig. 2). Lignin, which represented more than $50 \%$ of the total organic matter, was the predominant fraction followed by cellulose + hemicelluloses and a much small proportion of lipids and water-soluble compounds that did not reach $10 \%$ of the total organic matter. Therefore the most recalcitrant fractions to microbial attack predominated. This finding agreed with the $\mathrm{C}$ mineralization activity of this soil.

Burning affected all the organic matter fractions studied, although to a different extent (Fig. 2). In the surface soil, $72 \%$ of the cellulose + hemicelluloses disappeared, this fraction being the most affected by the fire followed by the water-soluble compounds ( $56 \%$ of losses), lignin (46\%) and lipids $(25 \%)$. The same trend was observed in the subsurface soil, but the disappearance of cellulose + hemicelluloses was higher $(81 \%)$ and that of watersoluble compounds lower $(46 \%)$, lignin and lipids presenting similar losses to those of the surface layer (46 and $26 \%$, respectively). Therefore the fire increased the more labile fractions and decreased the more resistant fractions (lignin + cellulose + hemicelluloses). The $\chi^{2}$ test indicated no significant differences between the surface layers from the burnt and unburnt soils, but significant differences in subsurface layers $(P \leq 0.05)$. Almendros et al. (1988) observed that fire increased the proportion of the shorter chain molecules of the lipid fraction, which may explain the increase of the $\mathrm{C}$ mineralization coefficient in both surface and subsurface soils immediately after the fire.

Although the number of samples is not enough to show possible correlations among the kinetic parameters (Table 2) and the different fractions of the organic matter, there was a high correlation ( $r=0.9420)$ between the content of the water-soluble compounds and the $\mathrm{C}$ mineralization rate of the labile $\mathrm{C}$ pool $(k)$, although this was at a low level of significance $(P=0.058)$.

Heating of the soil in the laboratory had similar effects on the distribution of the $\mathrm{C}$ compounds as 
\% O.M.

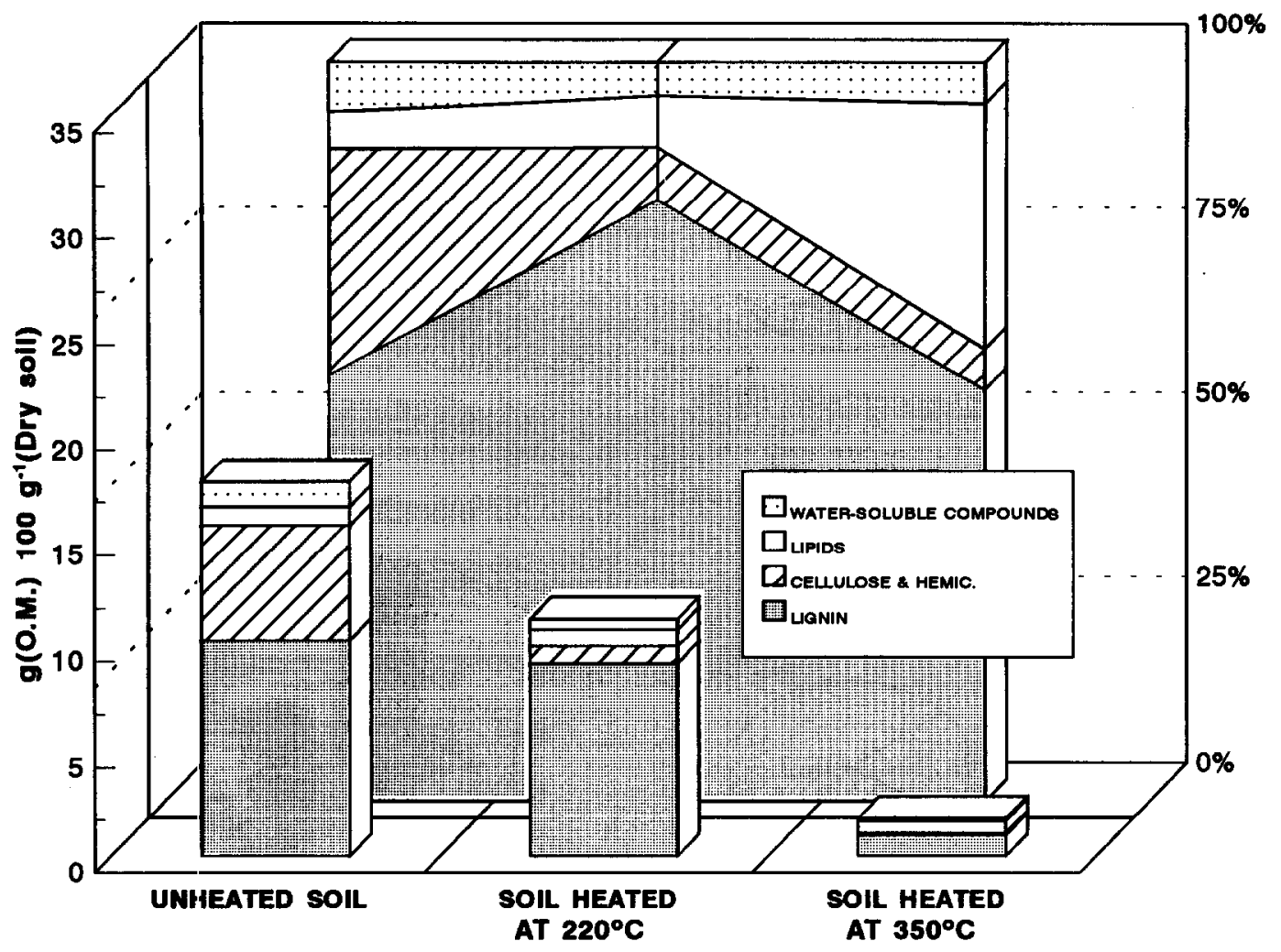

Fig. 3. Content (foreground of the figure) and changes in the percentage distribution (background) of the main groups of $\mathrm{C}$-containing compounds of the organic matter from the surface layer of the unheated soil or soils heated at 220 and $350^{\circ} \mathrm{C}$ in the laboratory.

those of wildfire (Fig. 3). At $220^{\circ} \mathrm{C}$, lignin, which was the most resistant fraction to the wildfire, only decreased by $11 \%$. Lipids declined in the same proportion, whereas cellulose + hemicelluloses was the fraction most affected by the heating $-85 \%$ of this fration disappearing during the heating process. At $350^{\circ} \mathrm{C}$, when only $10 \%$ of the initial organic matter remained, lipids were the least affected fraction because only $33 \%$ of them disappeared, whereas $90 \%$ of water-soluble compounds, cellulose + hemicelluloses and lignin fractions were destroyed. The percentage distribution clearly showed the decrease of cellulose + hemicelluloses and the increase of lipids when the temperature increased. The $\chi^{2}$ test showed that the crganic matter composition of the soils heated at 220 or $350^{\circ} \mathrm{C}$ were significantly different $(P \leq 0.05)$ from that of the unheated soil.

\section{Humus}

Figure 4 shows the percentage composition of the humified organic matter as well as the $C$ content for the different fractions expressed as a percentage of dry soil. In the unburnt soil, although the content of unhumified organic matter was high, the humified fraction clearly predominated. Approximately $50 \%$ of the humified organic matter corresponded to humic acids, whereas the other
$50 \%$ was quite uniformly distributed between fulvic acids and humin. The extraction and humification percentages as well as the HA-to-HA ratio (Table 3) were of the same order of magnitude as those found for other soils of the same area located at similar altitude and topography (Carballas et al., 1983). The organic matter was quite well humified and moderately polymerized with a predominance of HA according to the FA-to-HA ratio. The extractable $\mathrm{Fe}$ and $\mathrm{Al}$ content of the different fractions was not very high, which implies a low degree of complexation of the organic matter. The extractable $\mathrm{Al}$ content in each fraction was always higher than that of extractable $\mathrm{Fe}$, agreeing with the findings of Carballas et al. (1980) who studied the organo-metallic complexes in soils developed over granite from the same region.

The decrease of organic matter after fire was higher for the unhumified than for the humified fraction, and consequently the percentage of humification dramatically increased (see Fig. 4 and Table 3). There was a net increase of the humin fraction, as also observed by Almendros et al. (1990) in an oak forest affected by a fire. Humin was the predominant fraction in percentage distribution of the humic compounds, whereas HA and FA fractions decreased not only in percentage dis- 


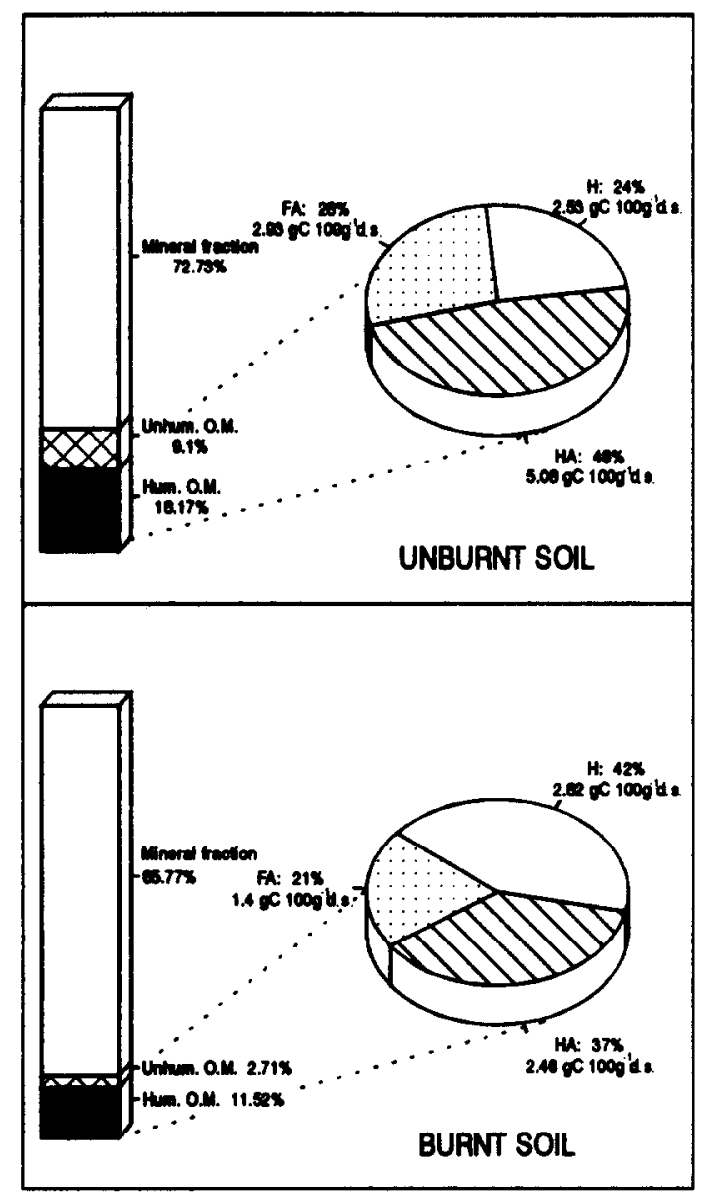

Fig. 4. Content and distribution of the different humic fractions from the $0-5 \mathrm{~cm}$ layer of the unburnt and the burnt soils.

tribution, but also in absolute amounts-the decrease being higher for HA. The effect of the fire on the organic matter was similar to a climatic maturing (Almendros et al,, 1984b) because although the extraction percentage decreased slightly, the percentage of humification increased considerably as well as the degree of polymerization, all pointing to a more stabilized organic matter. The fire increased the $\mathrm{Fe}$ and $\mathrm{Al}$ bounded to organic matter (from 39 to $91 \mathrm{mg} \mathrm{Fe} \mathrm{g}^{-1} \mathrm{C}$ and
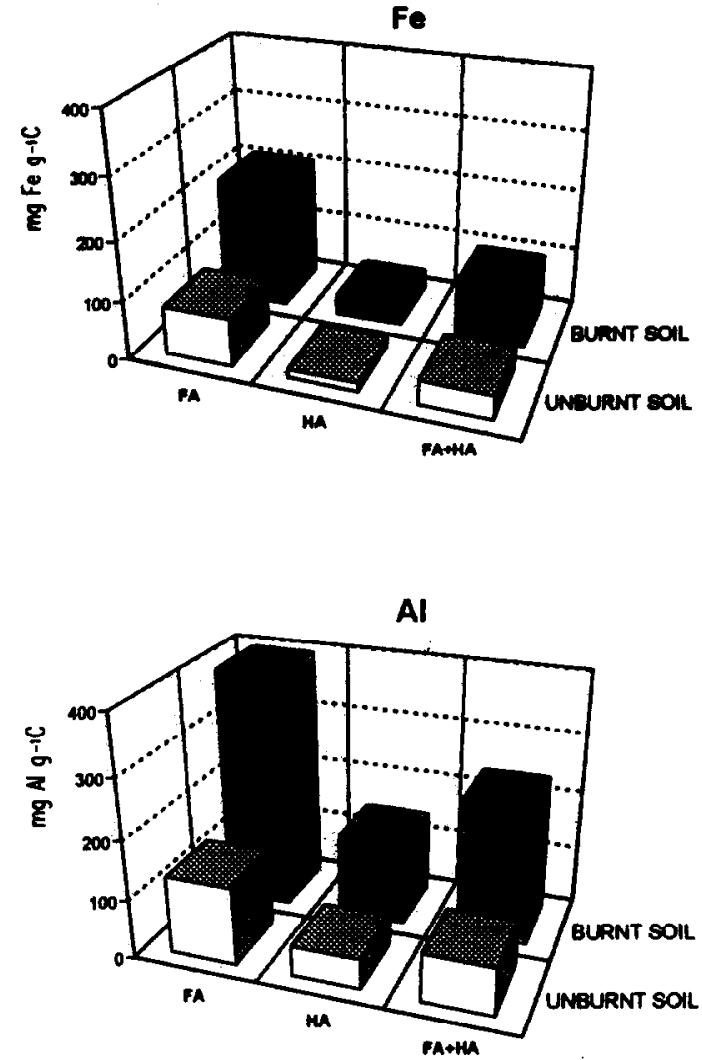

Fig. 5. Fe and Al bound to humic (HA) and fulvic (FA) acids from the $0-5 \mathrm{~cm}$ layer of the unburnt and the burnt soils.

from 79 to $223 \mathrm{mg} \mathrm{Al} \mathrm{g}^{-1} \mathrm{C}$ considering the $\mathrm{FA}$ and HA fractions together) (Fig. 5). The complexation capacity of FA was higher than that of HA; moreover organo-Al complexes predominated over organo-Fe complexes. These findings also contributed to an increase in organic matter stabilization (Jacquin et al., 1978; Cabaneiro et al., 1987).

Heating the soil in the laboratory at $220^{\circ} \mathrm{C}$ resulted in a decrease of humified and unhumified organic matter, the losses being 22 and $55 \%$ of the total organic matter, respectively (Fig. 6). Although HAs were still the predominant fraction, they underwent the highest decrease, in contrast to

Table 3. Characteristics of the humified organic matter after a high intensity wildfire and after heating under laboratory conditions

\begin{tabular}{|c|c|c|c|c|c|}
\hline Sample & Depth $(\mathrm{cm})$ & $\begin{array}{l}\text { Percentage extraction } \\
\left(C_{(\mathrm{FA}+\mathrm{HA})} C_{r}^{-1}\right)\end{array}$ & $\begin{array}{c}\text { Percentage } \\
\text { humification } \\
\left(C_{(\mathrm{FA}+\mathrm{HA}+\mathrm{H})} C_{t}^{-1}\right)\end{array}$ & FA-to-HA & $(\mathrm{Fe}+\mathrm{Al}) / \mathrm{C}$ \\
\hline $\begin{array}{l}\text { UB, } \\
B_{\mathbf{s}} \\
\mathbf{U H} \\
\mathbf{H}_{220}^{\mathbf{a}} \\
\mathbf{H}_{\mathbf{3 5 0}}^{\mathbf{z}}\end{array}$ & $\begin{array}{l}0-5 \\
0-5 \\
0-5 \\
0-5 \\
0-5\end{array}$ & $\begin{array}{c}51 \\
47 \\
44 \\
48 \\
8\end{array}$ & $\begin{array}{l}67 \\
81 \\
54 \\
67 \\
70\end{array}$ & $\begin{array}{l}0.58 \\
0.57 \\
0.46 \\
0.52 \\
0.60\end{array}$ & $\begin{array}{c}0.12 \\
0.32 \\
0.16 \\
0.29 \\
12.89\end{array}$ \\
\hline
\end{tabular}

UB, unburnt sample; B, burnt sample; UH, unheated sample; H, heated sample.

"Heating temperatures $\left({ }^{\circ} \mathrm{C}\right)$.

FA, fulvic acids; HA, humic acids; $H$, humin. 


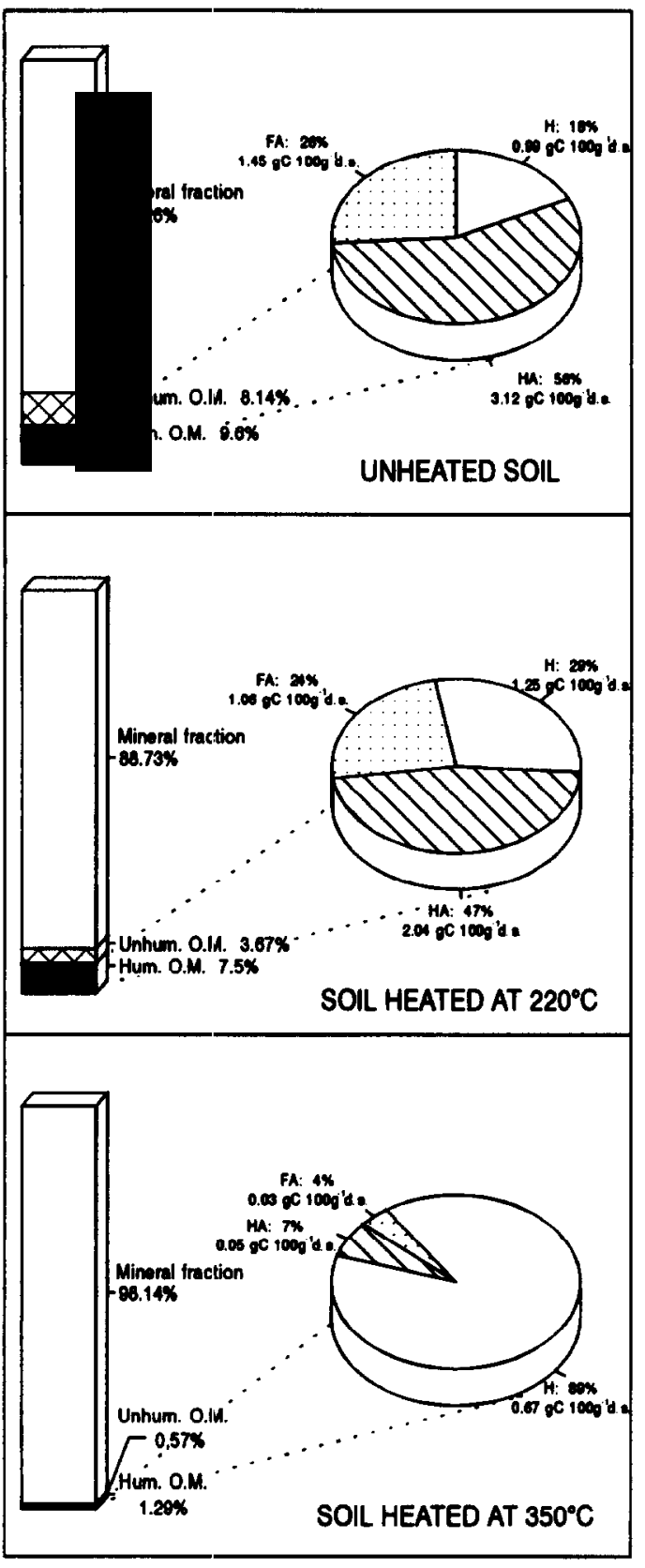

Fig. 6. Content and percentage distribution of the different humic fractions from the surface layer of the unheated soil or soils heated at 220 and $350^{\circ} \mathrm{C}$ in the laboratory.

humin which increased; however, humin was not high enough to ke the predominant fraction as it was after the wildfire. At $350^{\circ} \mathrm{C}$ the loss of organic matter was so high that the humin fraction was the only component of the organic matter that remained after the heating. Complexation of the organic matter with metals followed the same trend as in the case of the wildfire (Table 3). It increased after the heating, the association with $\mathrm{Al}$ being also favoured. At $220^{\circ} \mathrm{C}$ the increase of complexation was similar to that found for the wildfire, whereas at $350^{\circ} \mathrm{C}$ it was considerably increased. Nevertheless the high increase of organic matter bound to metals, particularly to $\mathrm{Al}$ (Al-to-C $=12.29$ ) observed at $350^{\circ} \mathrm{C}$, could not be a real effect but rather a consequence of the alteration of $\mathrm{Al}$ inorganic forms that became soluble at high $\mathrm{pH}(\mathrm{NaOH}$ at $\mathrm{pH} 13$, in which fraction $93 \%$ of extractable $\mathrm{Al}$ was obtained). This did not occur for Fe complexation capacity since at $350^{\circ} \mathrm{C}$ the Fe-to-C ratio accounted for only 0.60 .

The $\chi^{2}$ test showed that the percentage variation of the different humus fractions from the wildfire soil was significantly different $(P \leq 0.05)$ from that of the unburnt soil. Comparison of the unheated soil with the soil heated at $220^{\circ} \mathrm{C}$ at the laboratory showed that their composition were not significantly different, whereas the composition of the organic matter of the soil heated at $350^{\circ} \mathrm{C}$ was significantly different $(P \leq 0.01)$ from that of the unheated soil.

Acknowledgements - The authors thank Mr J. Salmonte and Ms B. Arnáiz for technical assistance. This research was supported by Consellería de Educación y Ordenación Universitaria de la Xunta de Galicia and by Comisión Interministerial de Ciencia y Tecnología (CICYT), Spain.

\section{REFERENCES}

Acea M.J. and Carballas T. (1996) Changes in physiological groups of microorganisms in soil following wildfire. FEMS Microbiology Ecology 20, 33-39.

Ahlgren Y.F. and Ahlgren C.E. (1960) Ecological effects of forest fires. The Botanical Review 26, 483-533.

Almendros G., Polo A., Ibañez J.J. and Lobo M.C. (1984a) Contribución al estudio de la infuencia de los incendios forestales en las características de la materia orgánica del suelo. Revue d'Écologie et Biologie du Sol 21, 7-20.

Almendros G., Polo A., Lobo M.C. and Ibañez J.J. (1984b) Contribución al estudio de la infuencia de los incendios forestales en las características de la materia orgánica del suelo. II. Transformaciones del humus por ignición en condiciones controladas de laboratorio. Revue d'Écologie et Biologie du Sol 21, 145-160.

Almendros G., Martin F. and González-Vila F.J. (1988) Effects of fire on humic and lipid fractions in a dystric xerochrept in Spain. Geoderma 42, 115-127.

Almendros G., González-Vila F.J. and Martín F. (1990) Fire-induced transformation of soil organic matter from an oak forest: an experimental approach to the effects of fire on humic substances. Soil Science 149, 158-168.

Almendros G., González-Vila F.J., Martín F., Fründ R. Lüdemann H.-D. (1992) Solid state NMR studies of fire-induced changes in the structure of humic substances. The Science of the Total Environment 117, 6374.

Andrén O. and Pauskian K. (1987) Barley straw decomposition in the field: a comparison of models. Ecology 68, $1190-1200$.

Bará S. (1981) Evolución de la composición de los suelos incendiados. I Jornadas Técnicas sobre prevención de incendios forestales. Lourizán, Pontevedra.

Beloso M.C., Villar M.C., Cabaneiro A., Carballas M. González-Prieto S.J. and Carballas T. (1993) Carbon and nitrogen mineralization in an acid soil fertilized 
with composted urban refuses. Bioresource Technology 45, 123-129.

Bremner J.M. (1965) Nitrogen availability indexes. In Methods of Soil Analysis. Part 2. Chemical and Microbiological Properties (C. A. Black, D. D. Evans, J. L. White, L. E. Ensminger, F. E. Clark, Eds), pp. 13241345. American Society of Agronomy, Madison.

Cabaneiro A., Choné Th. and Andreux F. (1987) The influence of seasonal changes and clay mineral on the biodegradation of ${ }^{14} \mathrm{C}-{ }^{15} \mathrm{~N}$ labelled proteinaceous material from Chlorella pyrenoidosa in an acidic soil. In Current Perspectives in Environmental Biogeochemistry (G. Giovannozzi-Sermanni and P. Nannipieri, Eds), pp. 5774. Consiglio Nazionale delle Ricerche, Roma.

Carballas M., Carballas T. and Jacquin F. (1979) Biodegradation and humification of organic matter in humiferous atlantic soils. Anales de Edafologia $y$ Agrobiologia 38, 1699-1717.

Carballas M., Cabaneiro A., Guitián-Rivera F. and Carballas T. (1980) Organo-metallic complexes in atlantic humiferous soils. Anales de Edafologia y Agrabiologia 39, 1033-1043.

Carballas M., Carballas T., Cabaneiro A., Villar M.C., Leiros M.C. and Guitián Ojea F. (1983) Suelos AC sobre granitos de Galicia (NO de España) con especial referencia al ranker atlántico. III Fracción orgánica. Anales de Edafologia y Agrobiologia 42, 1781-1814.

Chandler C., Cheney Ph., Thomas Ph., Trabaud L. and Williams D. (1983). Fire in Forestry. Vol. I. Forest Fire Behavior and Effects. Wiley, New York.

Choné Th., Jacquin F. and Yagui M. (1974) Emploi de ${ }^{14} \mathrm{C}$ et ${ }^{45} \mathrm{Ca}$ comme éléments traceur de l'humification. Bulletin de l'École Nationale Superieure d'Agronomie et des Industries Alimentaires de Nancy 15, 69-85.

Diaz-Fierros F., Gil Sotres F., Cabaneiro A., Carballas T., Leirós de la Peña M.C. and Villar Celorio M.C. (1982) Efectos erosivos de los incendios forestales en suelos de Galicia. Anales de Edafologia $y$ Agrobiologia 41, 627-639.

Diaz-Fierros F., Benito Rueda E. and Pérez Moreira R. (1987) Evaluation of the U.S.L.E. for the prediction of erosion in burnt forest areas in Galicia (N.W. Spain). Catena 14, 189-199.

Diaz-Fierros F., Villar M.C., Gil F., Carballas M., Leirós M.C., Carballas T. and Cabaneiro A. (1988) Effect of cattle slurry fractions on nitrogen mineralization in soil. Journal of Agricultural Science, Cambridge 110, 491497.

Díaz Raviña M., Prieto A., Acea M.J. and Carballas T. (1992) Fumigation-extraction method to estimate microbial biomass in heated soils. Soil Biology and Biochemistry 24, 259-264.

Duchaufour P. and Jacquin F. (1966) Nouvelles recherches sur l'extraction et le fractionnement des composés humiques. Bulletin de l'École Nationale Superieure d'Agronomie et des Industries Alimentaires de Nancy 8, $1-24$

Feller M.C. (1988) Relationships between fuel properties and slashburning-induced nutrient losses. Forest Science 34, 998-1015.

Fritze H., Smolander A., Levula T., Kitunen V. and Mälkönen E. (1994) Wood-ash fertilization and fire treatments in a Scots pine forest stand: effects on the organic layer, microbial biomass, and microbial activity. Biology and Fertility of Soils 17, 57-63.

Giovannini G., Lucchesi S. and Giachetti M. (1987) The natural evolution of a burned soil: a three-year investigation. Soil Science 143, 220-226.

Giovannini G., Lucchesi S. and Giachetti M. (1990) Effects of heating on some chemical parameters related to soil fertility and plant growth. Soil Science 149, 344 350.
González-Prieto S.J., Carballas M. and Carballas T. (1991) Mineralization of a nitrogen-bearing organic substrate model ${ }^{14} \mathrm{C},{ }^{15} \mathrm{~N}$-glycine in two acid soils. Soil Biology and Biochemistry 23, 53-63.

González-Prieto S.J., Carballas M., Villar M.C., Beloso M.C., Cabanciro A. and Carballas T. (1993) Carbonand nitrogen-containing compounds in composted urban refuses. Bioresource Technology 45, 115-121.

Guckert A., Roger P. and Jacquin F. (1968) Contribution à l'utilisation de techniques radioisotopiques pour l'étude de la matière organique du sol. Bulletin de l'École Nationale Superieure d'Agronornie et des Industries Alimentaires de Nancy 10, 69-100.

Guitián Ojea F. and Carballas T. (1976) Técnicas de Análisis de Suelos. Pico Sacro, Santiago de Compostela.

Jacquin F., Carballas $M$. and Carballas T. (1978) Interaction entre les ions aluminium et la mineralisation de la matière organique dans les sols humifères atlantiques. Comptes Rendues de l'Academie de Sciences, pp. 511-514. Paris 286, Série D.

Kang B.T. and Sajjapongse A. (1980) Effects of heating on properties of some soils from Southern Nigeria and growth of rice. Plant and Soil 55, 85-95.

Khanna P.K. and Raison R.J. (1986) Effect of fire intensity on solution chemistry of surface soil under a Eucalyptus pauciflora forest. Australian Journal of Soil Research 24, 423-434.

Kononova M. M. (1961) Soil Organic Matter. Its Nature. its Role in Soil Formation and in Soil Fertility. Pergamon, Oxford.

Kutiel P. and Kutiel H. (1989) Effects of a wildfire on soil nutrients and vegetation in an Aleppo pine forest on Mount Carmel, Israel. Pirineos 134, 59-74.

Marion G.M., Moreno J.M. and Oechel W.C. (1991) Fire severity, ash deposition, and clipping effects on soil nutrient in chaparral. Soil Science Society of America Journal 55, 235-240.

Nishita H. and Haug R.M. (1972) Some physical and chemical characteristices of heated soils. Soil Science 113, 430-442.

Prieto-Fernández A., Villar M.C., Carballas M. and Carballas T. (1993) Short-term effects of a wildfire on the nitrogen status and its mineralization kinetics in an atlantic forest soil. Soil Biology and Biochemistry 25, $1657-1664$

Salgado J., González M.I., Armada J., Paz-Andrade M.I., Carballas M. and Carballas T. (1995) Loss of organic matter in Atlantic forest soils due to wildfires. Calculation of the ignition temperature. Thermochimica Acta 259, 165-175.

Shindo H. and Urabe M. (1993) Changes in the humus composition of volcanic ash soils by heating at various temperatures. Soil Science and Plant Nutrition 39, 189192.

Stanford G. and Smith S.J. (1972) Nitrogen mineralizatión potentials of soils. Soil Science Society of America Proceeding 36, 465-472.

Stevenson F. J. (1965) Gross chemical fractionation of organic matter. In Methods of Soil Analysis. Part 2. Chemical and Microbiological Properties (C. A. Black, D. D. Evans, J. L. White, L. E. Ensminger and F. E. Clark, Eds), pp. 1409-1414. American Society of Agronomy, Madison.

Tukey S. W. (1953) The Problem of Multiple Comparisons. Princeton University Press, Princeton.

Ulery A.L., Graham R.C. and Amrhein C. (1993) Woodash composition and soil $\mathrm{pH}$ following intense burning. Soil Science 156, 358-364.

Updegraff K., Pastor J., Bridgham S.D. and Johnston A. (1995) Environmental and substrate controls over carbon and nitrogen mineralization in northern wetlands. Ecological Applications 5, 151-163. 
Vázquez F.J., Aceà M.J. and Carballas T. (1993) Soil microbial populations after wildfire. FEMS Microbiology Ecology 13, 93-104.
Zak D.R., Grigal D.F. and Ohmann L.F. (1993) Kinetics of microbial respiration and nitrogen mineralization in Great Lakes Forests. Soll Science Society of America Journal 57, 1100-1106. 